\title{
Special themed issue: Education in clinical chemistry and laboratory medicine in various European countries
}

\section{The regulation of clinical chemistry in Slovenia}

Pika Mesko Brguljan

Clinical Biochemistry and Hematology Department, University Clinic for Respiratory Diseases and Allergy Golnik, Golnik, Slovenia

Corresponding author: pika.mesko@klinika-golnik.si

\begin{abstract}
The practice of medical biochemistry in Slovenia includes clinical biochemistry (including toxicology, therapeutic drug monitoring, endocrinology, molecular diagnostics, immunology), hematology and coagulation. To start the vocational medical biochemistry training programme it's necessary to have a completed university degree (second cycle) in pharmacy, chemistry, biochemistry, medicine or other relevant university study and 1 year supervised practical training in medical laboratories, completed with mandatory state exam at Ministry of Health. The duration of vocational training programme is 4 years and is completed with final exam. The title after passed final examination is Medical biochemistry specialist. In 0ctober 2005 EC4 (Communities Confederation of Clinical Chemistry and Laboratory Medicine) approved Equivalence of standards of Slovenian national standards for medical biochemistry specialists. Since 2006 it is mandatory to be registered and to have valid license for medical biochemistry specialists and other professionals in laboratory medicine with at least university degree (second cycle) of education.

Laboratory medicine in Slovenia is regulated globally through the Law of health-care activity and particularly through the Bylaw of laboratory medicine. The latter is based on standard ISO 15189, ratified in 2004. The Bylaw envisages granting working license to laboratories, valid for 5 years period. Granting of working licenses is ongoing process and first licenses have been granted in 2009. Important improvement toward the quality requirements for medical laboratories can be observed in the last 5 years. Parallel with the Bylaw of medical laboratories, Slovenian Accreditation $(S A)$, the legal national accreditation body, started the initiative for accreditation of medical laboratories according to ISO 15189. It is in the implementation phase.
\end{abstract}

Key words: education; training; EC4; quality

\section{Introduction}

Clinical chemistry and laboratory medicine is a scientific discipline within medicine. The situation on education, training and quality management in clinical chemistry differs among the European countries $(1,2)$. The aim of this paper is to present the current situation on education, training and regulation of laboratory professionals as well as quality requirements for medical laboratories in Slovenia.

\section{Profession of medical biochemists in Slovenia}

Clinical chemistry, the largest subdiscipline of laboratory medicine, in Slovenia is named Medical biochemistry, in concordance with post-graduate training of medical biochemistry specialists. The practice of medical biochemistry in Slovenia includes clinical biochemistry (including toxicology, therapeutic drug monitoring, endocrinology, mo- 
lecular diagnostics, immunology), hematology and coagulation. Vocational training programme also includes informative knowledges in microbiology (2 months) and transfusiology (1 month), medical biochemistry specialists could not be appointed to head the laboratories in these two subdisciplines of laboratory medicine. The competent specialists in other subdisciplines of laboratory medicine in Slovenia are medical doctors with vocational training in microbiology, transfusiology or cyto/histopathology. In order to start the vocational medical biochemistry training programme, it's necessary to have a completed university degree (second cycle) in pharmacy, chemistry, biochemistry, medicine or other relevant university study, as well as 1 year of supervised practical training in medical laboratories of different subdisciplines in laboratory medicine, completed with mandatory state exam at Ministry of Health of Republic Slovenia. Depending on graduate and post-graduate (where applicable) degree (chemistry, pharmacy, medicine, etc) there are some differences in theoretical and practical parts of vocational training programme, which is individually formed. The Slovenian Chamber of Laboratory Medicine (SCLM) is competent to check the adequacy of the other relevant university (second cycle) study programmes (for example biology, veterinary medicine) to enter the vocational training programme. The duration of vocational training programme is 4 years and is completed with final exam (theoretical and practical). Vocational training for medical biochemistry specialists is regulated by the national bylaw document issued by the Ministry of Health $(\mathrm{MH})$ and the Slovenian Chamber of Laboratory Medicine. Vocational training in approved laboratories at university clinics and teaching hospitals is affiliated to the university (Faculty of Pharmacy) and approved and supervised by SCLM and $\mathrm{MH}$. The title after passed final examination is Medical biochemistry specialist. In the vocational training programme the complete analytical process, including pre- and post-analytical (including interpretation and clinical advice) phases are included. Since the professional activities of medical biochemistry specialist include management responsibilities, the important part of training programme is laboratory organization and management with informatics. There is no difference in responsibilities, duties and competences between medical biochemistry specialists which differ in their university degree education and they have equal positions in the health care system. In December 2010 in Slovenia 72 medical biochemistry specialists are active (SCLM database).

In 2004 Slovenia became the member of the European Union and the Slovenian Association for Clinical Chemistry (SACC), representative professional association in IFCC (International Federation of Clinical Chemistry and Laboratory Medicine), FESCC (Federation of European Societies of Clinical Chemistry and Laboratory Medicine) and EC4 (Communities Confederation of Clinical Chemistry and Laboratory Medicine) (now merging to EFCC - European Federation of Clinical Chemistry and Laboratory Medicine), apply to get the Equivalence of standards of education of medical biochemistry specialists at EC4. EC4 Registration Commission checked the equivalence of EC4 Register standards (European Syllabus) $(3,4)$ with Slovenian national standards and General Assembly approved Equivalence of standards in October 2005. Afterwards medical biochemistry specialists have the possibility to apply for registration at EC4RC (through National Registration Commission at SACC) and after the EC4 registration, get the right to use the professional title European Specialist in Clinical Chemistry and Laboratory Medicine (EurClinChem) (4-6). Until now, 45 Slovenian medical biochemistry specialists have been registered as EurClinChem (SACC database). The registration is valid for a 5 years period and the first Slovenian EurClinChem should re-register in the year 2011. The criteria for re-registration, including continuing professional development (CPD) and continuing education (CE), have been already prepared by the national registration commission (NCCRC), approved at executive board of SACC and sent to approval at EC4RC.

SCLM has got public authority for laboratory professionals (not for MD) from $\mathrm{MH}$ in June 2006. SCLM is empowered for registration and licensing of medical biochemistry specialists and other professionals in laboratory medicine with at least uni- 
versity degree (second cycle) of education (and state exam at $\mathrm{MH}$ after 1 year of practice in laboratory medicine), supervising of vocational training in medical biochemistry and to conduct performance review with counseling of laboratory professionals. Until December 2010, SCLM has registered 177 laboratory medicine professionals, among them 147 have got the license (72 specialists, only specialists have the right to head the laboratory) (SCLM database). License is valid for 7 years, after this period the conditions for re-licensing are checked (among them CPD, CE). An important issue for valid license is also to work in accordance with Slovenian Code of Conduct in Laboratory Medicine. The registered specialists in EC4RC (EurClinChem) have to undertake also to comply with the EC4 Code of Conduct (7).

\section{Quality requirements in laboratory medicine}

Laboratory medicine in Slovenia is regulated globally through the Law of health-care activity and particularly through the Bylaw of laboratory medicine. The latter is based on the standard ISO 15189 (8), ratified in 2004. The Bylaw have been prepared by the working group, appointed by Ministry of Health in collaboration with professional associations, chambers and four Slovenian Collegiate Boards (SBC) in the field of laboratory medicine in Slovenia (SCB for laboratory diagnostics (clinical chemistry), SCB for microbiology and immunology, SCB for transfusion medicine, SBC for pathology and forensic medicine). SCBs represent the advisory commission at Ministry of Health which harmonizes the proposals from clinics, professional associations, chambers, healthcare institutions, colleges and other education centers or individual professionals. The members of SCBs are appointed by professional associations, clinical institutes and relevant faculties (or professional chambers). In the case of SCB for laboratory diagnostics (clinical chemistry), these are Slovenian Association for Clinical Chemistry, Clinical Institute for Clinical Chemistry and Biochemistry of University Medical Centre Ljubljana and Faculty of Pharmacy (Chair of Clinical Biochemistry) of University Ljubljana.
The Bylaw covers the entire scope of the Standard ISO 15189, in a less pretentious way (organization, quality assurance management, personnel, environment and premises, equipment and documentation...). The quality criteria for preanalytical, analytical and postanalytical phase are stated. POCT and laboratory safety are included. Laboratory medicine in Slovenia comprises four scientific fiel$\mathrm{ds}$; these are medical biochemistry (clinical chemistry), clinical/medical microbiology, transfusiology and cyto/histopathology. The four fields of sciences base on four nationally (internationally) recognized areas of medical specialization for which the structured post-graduate training programme exists. The Bylaw envisages granting laboratory working license (for subdiscipline of medical biochemistry, clinical/medical microbiology, transfusiology or cyto/histopathology), if the laboratory complies with prescribed minimal standards. The Bylaw requirement is also that the head of the laboratory should be a competent laboratory medicine specialist (medical biochemistry specialist if the laboratory working license is granted for the subdiscipline of medical biochemistry) with responsibility for, and authority over a laboratory.

According to the Bylaw, the laboratories are assessed by the commissions, appointed by $\mathrm{MH}$. The assessors should be laboratory specialists with training in auditing of quality management system in medical laboratories. Laboratory working license is issued by Ministry of Health, valid for a 5 year period. In 2005 Ministry of Health made a call to medical laboratories to apply for working license. 239 written applications were assembled ( $66 \%$ in clinical chemistry), many of them incomplete (9). The granting working licenses is ongoing process and the first licenses has been granted already ( $50 \mathrm{for}$ medical biochemistry, 12 for clinical/medical microbiology, 16 for cyto/histopathology, 14 for transfusiology). Important improvement toward the quality requirements for medical laboratories can be observed in the last 5 years.

Parallel with the Bylaw of medical laboratories Slovenian Accreditation (SA), the legal national body, competent and reliable at the national and international level, started the initiative for accreditation of medical laboratories according to ISO 15189. 
In September 2008 SA (9) made a call to medical laboratories to apply for pilot project of accreditation. During this introduction period SA will perform several accreditation procedures under the special conditions. Accreditation procedures will be performed according to Regulations of Accreditation Procedures with particular adaptations. Up to the deadline, four applications were put in. SA will make the final selection with regard to complexity of the laboratory scope and on the basis of pre-assessment survey. The pilot accreditation assessments will be performed by SA assessors with the help of experienced foreign professionals.

\section{Conclusion}

Medical biochemistry (clinical chemistry) in Slovenia is the biggest subdiscipline in laboratory medicine, it is a regulated profession.

\section{References}

1. Rossier M, Blaton V, Franzini C, Queralto JM, Palicka V. FESCC Survey on Accreditation and Post-Graduated Training in Clinical Chemistry in European Countries. Clin Chem Lab Med 2000;38:371-6.

2. Huisman W, Horvath AR, Burnett D, Blaton V, Czikkely R, Jansen RTP, et al. Accreditation of medical laboratories in the European Union. Clin Chem Lab Med 2007;45:268-75.

3. EC4 Register. Available at: http://www.ec4register.eu. Accessed December 31, 2010.

4. Gurr E, Koeller U, Blaton V, Lund E, Harmoinen A, Zerah S, et al. The European Register for Specialists in Clinical Chemistry and Laboratory Medicine: Guide to the Register Version 2-2003 and Procedure for Re-registration. Clin Chem Lab Med 2003;41:238-47.

5. Zerah S, McMurray J, Bousquet B, Baum H, Beastall GH, Blaton $V$, et al. European Communities of Clinical Chemistry, EC4 Register Commission. EC4 European Syllabus for Po-
The education of medical biochemistry specialists matches European Syllabus, as approved by EC4 RC. For medical biochemistry specialists and other professionals in laboratory medicine with at least university degree (second cycle) of education, it is mandatory to be registered and to have a valid license.

Laboratory medicine in Slovenia is regulated globally through the Law of health-care activity and particularly through the Bylaw of laboratory medicine. The latter is based on standard ISO 15189, ratified in 2004. Accreditation of medical laboratories according to ISO 15189 is in the implementation phase.

st-Graduate Training in Clinical Chemistry and Laboratory Medicine: version 3 - 2005. Clin Chem Lab Med 2006;44:1 1020.

6. McMurray J, Zerah S, Hallworth M, Schuff-Werner P, Haushofer A, Szekeres T, et al. The European Register of Specialists in Clinical Chemistry and Laboratory Medicine: Guide to the Register; Version 3-2010. Clin Chem Lab Med 2010;48:999-1008.

7. McMurray J, Zerah S, Hallworth M, Koeller U, Blaton V, Tzatchev K, et al. The European Register of Specialists in Clinical Chemistry and Laboratory Medicine: Code of Conduct, Version 2 - 2008. Clin Chem Lab Med 2009;47:372-5.

8. ISO EN 15189:2003, 2007. Medical laboratories - particular requirements for quality and competence.

9. Mesko Brguljan P, Bozic B, Bratoz S. Legislation of laboratory medicine in Slovenia. Clin Chem Lab Med 2009; 47(Suppl):B039. 


\section{Klinička kemija u Sloveniji - regulacija struke}

\section{Sažetak}

Praksa medicinske biokemije u Sloveniji uključuje kliničku biokemiju (zajedno s toksikologijom, terapijskim praćenjem koncentracije lijekova, endokrinologijom, molekularnom dijagnostikom, imunologijom), hematologiju i koagulaciju. Za upis programa specijalističkog usavršavanja iz medicinske biokemije potrebno je završiti sveučilišni diplomski studij farmacije, kemije, biokemije, medicine ili neke druge relevantne znanosti te završiti godinu dana pripravničkog staža u medicinskom laboratoriju koji završava državnim stručnim ispitom pri Ministarstvu zdravstva. Specijalistički program traje 4 godine nakon čega je potrebno položiti završni ispit. Po završetku specijalističkog programa dobije se titula „specijalist medicinske biokemije". U listopadu 2005. EC4 je odobrila slovenske nacionalne standarde za specijaliste medicinske biokemije kao ekvivalentne standardima EC4. Od 2006. specijalisti medicinske biokemije i ostali stručnjaci laboratorijske medicine sa završenim sveučilišnim diplomskim studijem moraju se obavezno registrirati te posjedovati važéu dozvolu za rad (licencu).

Laboratorijska medicina u Sloveniji globalno je regulirana Zakonom o zdravstvenoj djelatnosti, te Pravilnikom o laboratorijskoj medicini. Pravilnik se temelji na standardu ISO 15189, ratificiranom 2004. Pravilnik predviđa odobravanje dozvole za rad (licence) laboratorijima na razdoblje od 5 godina. Odobravanje licenci je u tijeku, a prve su bile izdane 2009. U posljednjih 5 godina može se primijetiti značajno poboljšanje u skladu sa zahtjevima za kvalitetu medicinskih laboratorija. Paralelno s Pravilnikom o medicinskim laboratorijima, Slovenska Akreditacija (engl. Slovenian Acreditation, SA), pravno nacionalno akreditacijsko tijelo, započela je s inicijativom akreditacije medicinskih laboratorija prema standardu ISO 15189. Akreditacija je u fazi implementacije.

Ključne riječi: školovanje; usavršavanje; EC4; kvaliteta 